\title{
Evidence for intense REE scavenging at cold seeps from the Niger Delta margin
}

\author{
G. Bayon ${ }^{a}{ }^{*}$, D. Birot ${ }^{a}$, L. Ruffine ${ }^{a}$, J.-C. Caprais ${ }^{b}$, E. Ponzevera ${ }^{a}$, C. Bollinger ${ }^{c, d}$, J.-P. Donval $^{a}$,

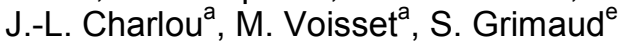

\author{
a Ifremer, Département Géosciences Marines, F-29280 Plouzané, France \\ ${ }^{\mathrm{b}}$ Ifremer, Département Etude des Ecosystèmes Profonds, F-29280 Plouzané, France \\ ${ }^{c}$ Université Européenne de Bretagne, F-35000 Rennes, France \\ d Université de Brest, IUEM, CNRS UMS 3113, F-29280 Plouzané, France \\ e TOTAL, CSTJF Av. Larribau, F-64019 Pau Cedex, France \\ *: Corresponding author: G. Bayon, Tel.: + 33298224630 ; fax: + 33298224570 ;
email address : gbayon@ifremer.fr
}

\begin{abstract}
:
For many trace elements, continental margins are the location of intense exchange processes between sediment and seawater, which control their distribution in the water column, but have yet to be fully understood. In this study, we have investigated the impact of fluid seepage at cold seeps on the marine cycle of neodymium. We determined dissolved and total dissolvable (TD) concentrations for REE and well-established tracers of fluid seepage $\left(\mathrm{CH}_{4}\right.$, TDFe, TDMn), and $\mathrm{Nd}$ isotopic compositions in seawater samples collected above cold seeps and a reference site (i.e. away from any fluid venting area) from the Niger Delta margin. We also analyzed cold seep authigenic phases and various core-top sediment fractions (pore water, detrital component, easily leachable phases, uncleaned foraminifera) recovered near the hydrocast stations.
\end{abstract}

Methane, TDFe and TDMn concentrations clearly indicate active fluid venting at the studied seeps, with plumes rising up to about $100 \mathrm{~m}$ above the seafloor. Depth profiles show pronounced REE enrichments in the non-filtered samples (TD concentrations) within plumes, whereas filtered samples (dissolved concentrations) exhibit slight REE depletion in plumes relative to the overlying water column and display typical seawater REE patterns. These results suggest that the net flux of REE emitted into seawater at cold seeps is controlled by the presence of particulate phases, most probably Fe-Mn oxyhydroxides associated to resuspended sediments. At the reference site, however, our data reveal significant enrichment for dissolved REE in bottom waters, that clearly relates to diffusive benthic fluxes from surface sediments.

Neodymium isotopic ratios measured in the water column range from $\varepsilon_{N d} \sim-15.7$ to -10.4 . Evidence that the $\varepsilon_{\mathrm{Nd}}$ values for Antarctic Intermediate waters (AAIW) differed from those reported for the same water mass at open ocean settings shows that sediment/water interactions take place in the Gulf of Guinea. At each site, however, the bottom water $\varepsilon_{N d}$ signature generally differs from that for cold seep minerals, easily leachable sediment phases, and detrital fractions from local sediments, ruling out the possibility that seepage of methane-rich fluids and sediment dissolution act as a substantial source of 
dissolved Nd to seawater in the Gulf of Guinea. Taken together, our data hence suggest that coprecipitation of $\mathrm{Fe}-\mathrm{Mn}$ oxyhydroxide phases in sub-surface sediments leads to quantitative scavenging of dissolved REE at cold seeps, preventing their emission into bottom waters. Most probably, it is likely that diffusion from suboxic surface sediments dominates the exchange processes affecting the marine $\mathrm{Nd}$ cycle at the Niger Delta margin.

\section{Highlights}

Fluid seepage at margins does not represent a source of dissolved REE to the ocean. FeMn oxide precipitation at cold seeps leads to quantitative removal of dissolved REE. D Diffusive fluxes from suboxic sediments probably play a major role in marine $\mathrm{Nd}$ cycle.

Keywords : rare earth elements; neodymium isotopes; seawater; cold seeps; Fe-Mn oxyhydroxides; benthic fluxes 


\section{1 - Introduction}

\subsection{The sources of dissolved neodymium to the ocean}

The distribution of neodymium isotope ratios in seawater matches remarkably well global ocean circulation patterns (see Frank, 2002; Goldstein and Hemming, 2003 for summaries). On this basis, neodymium isotopes have been increasingly used as water-mass tracers in marine authigenic precipitates and biogenic sediments to improve understanding of past ocean circulation (e.g., Rutberg et al., 2000; Piotrowski et al., 2005, 2009; Scher and Martin, 2004; Pucéat et al., 2005; van de Flierdt et al., 2006; Haley et al., 2008; Gutjahr et al., 2008; Robinson and van de Flierdt, 2009). Despite significant interest in using Nd isotopes for paleoceanographic studies, the way water masses acquire their $\mathrm{Nd}$ isotopic composition is not fully understood yet. In fact, the sources of dissolved Nd and other rare earth elements (REE) to the ocean are still being debated. Hydrothermal systems probably do not contribute much to the dissolved $\mathrm{Nd}$ oceanic budget, because $\mathrm{Nd}$ and other rare earth elements emitted at vent sites are efficiently scavenged by iron-rich plumes (e.g., Michard et al., 1983; German et al., 1990; Halliday et al., 1992; Sherrel et al., 1999). To a first approximation, therefore, dissolved neodymium in seawater is derived from continental inputs, with possible contributions from rivers (e.g., Goldstein and Jacobsen, 1987; Elderfield et al., 1990; Sholkovitz, 1995; Sholkovitz et al., 1999; Sholkovitz and Szymczak, 2000), dissolution of settling particles (e.g., German and Elderfield, 1990; Greaves et al., 1994; Tachikawa et al., 1999; Nozaki and Alibo, 2002; Bayon et al., 2004; Jacobson and Holmden, 2006), submarine groundwater discharge (Johannesson and Burdige, 2007), and benthic fluxes (e.g., Elderfield and Sholkovitz, 1987; Sholkovitz et al., 1992; Amakawa et al., 2000; Lacan and Jeandel, 2005; Arsouze et al., 2007, 2009). The Nd isotopic composition in ocean basins hence globally reflects the age of surrounding terranes. 
A major advance in the understanding of the marine $\mathrm{Nd}$ cycle has been the recognition over recent years that the $\mathrm{Nd}$ isotopic signature of water masses could be modified along continental and island margins, without any significant additional input of dissolved $\mathrm{Nd}$ (Jeandel et al., 1998; Tachikawa et al., 1999; Lacan and Jeandel, 2001; Lacan and Jeandel, 2004a; Lacan and Jeandel, 2004b; Lacan and Jeandel, 2005; Andersson et al., 2008; Amakawa et al., 2009). Lacan and Jeandel (2005) referred to this process as 'boundary exchange', suggesting that ocean margins were an important component of the oceanic $\mathrm{Nd}$ cycle. Recent modeling studies even proposed that exchange processes at margins could represent the dominant source of dissolved Nd to the ocean (up to 90\%), far more important than inputs from rivers and aeolian particles taken together (Arzouse et al., 2007; Arzouse et al., 2009). However, despite the evidence that sediment/water interactions at margins play a key role in the marine $\mathrm{Nd}$ geochemistry, the mechanisms of this exchange are not well understood. Dedicated studies are now needed to better constrain the processes behind boundary exchange. There are few sources of dissolved REE at margins that could possibly impact the oceanic Nd budget at a global scale, which include dissolution of lithogenic sediments, benthic fluxes from sub-surface sediments, and venting of methane-rich fluids from reducing sediments. The goal of the present work is to assess, for the first time, the potential importance of this latter source (i.e. fluid seepage) in the marine Nd cycle.

\subsection{Cold seeps and emission of methane-rich fluids on margins}

Venting of methane-rich fluids is a widespread phenomenon at ocean margins. Although there are large uncertainties in estimating the mass of methane stored in marine sediment (Judd et al., 2002), it is likely that methanogenesis occurs over at least $30 \%$ of the world's continental margins (Hovland and Judd, 1992). Seafloor expressions of focused fluid venting are commonly referred to as cold seeps, which include a large range of geological structures 
such as pockmarks, mud volcanoes, gas chimneys, and brine pools. In marine sediment, methane is typically produced through microbial degradation of organic matter under anoxic conditions, after a specific sequence of reactions, which greatly affect pore water chemistry (e.g. Froelich et al., 1979; Thomson et al., 1993). In particular, organic matter degradation in reducing sediments can lead to significant enrichments (from 10 to 1,000 times) in the rare earth element contents of pore waters relative to seawater (Elderfield and Sholkovitz, 1987; Haley et al., 2004).

Because methane, as a greenhouse gas, plays a key role in the Earth's climate, there have been significant efforts to quantify methane fluxes at continental margins, and assess their relevance to the global carbon budget (e.g., Judd et al., 2002; Milkov et al., 2003; Kopf, 2003; Wallmann et al., 2006). In marked contrast, however, very little is known about trace element biogeochemistry at cold seeps, and the impact of fluid seepage on ocean chemistry. A few dedicated studies have focused on the geochemical cycling of barium at cold seeps from the Peru and California margins (Torres et al., 1996; 2002; Castellini et al., 2006; McQuay et al., 2008). These studies showed that emission of dissolved Ba at vent sites had significant local impact on the marine Ba budget. Similarly, fluid seepage on continental margins could also represent a potential source of dissolved Nd to the ocean, but to the best of our knowledge, there has been no comparable work for the rare earth elements.

Here, we report dissolved and total dissolvable (TD) REE concentrations, Nd isotopic compositions, and data for well-established tracers of fluid seepage $\left(\mathrm{CH}_{4}, \mathrm{TDFe}, \mathrm{TDMn}\right)$ for seawater samples collected in the water column above deep-sea fluid-escape structures from the Niger Delta (Gulf of Guinea, West African margin). In addition, we also present data for a series of pore water samples, sub-surface sediments and associated authigenic precipitates 
113 from the same area. Our data demonstrate that fluid seepage at cold seeps is not accompanied

114 by emission of dissolved REE into bottom waters, because Fe-oxyhydroxide co-precipitation 115 leads to quantitative REE scavenging at vent sites.

\section{2 - Regional setting}

\subsection{Studied sites}

119 The area investigated in this study is located on the Niger Delta, between $500 \mathrm{~m}$ and $1800 \mathrm{~m}$ water depth (Fig. 1). A large number of seafloor structures related to fluid venting (i.e., mud volcanoes, diapirs, pockmarks) were reported previously on the Niger Delta deep province (Mascle et al., 1973; Brooks et al., 1994; Cohen and McClay, 1996; Bayon et al., 2007; Sultan et al., 2010). In this study, all water and sediment samples were collected from three distinct areas (Fig. 1). 1) A pockmark-rich area (water depth: 550m; hereafter referred to as Pockmark Field), characterized by the presence of large seafloor depressions with irregular shapes (Fig. 2a). 2) A mud volcano ( $680 \mathrm{~m}$ water depth; about $1 \mathrm{~km}$ wide) situated on the north flank of a dome, composed of two distinct volcanic cones with a mean elevation of about 40m (Fig. 2b). The dome also exhibits a wide range of fluid venting structures related to the presence of faults and/or gas hydrate reservoirs. 3) An area located at $~ 1780 \mathrm{~m}$ water depth (Reference Site), where several submarine slope failures were reported previously (Sultan et al., 2007), but which is not characterized by any active fluid seepage. In addition, a few pore water samples were collected from sub-surface sediments recovered from other active pockmarks of this Niger Delta area (see Bayon et al., 2007).

\subsection{Hydrography of the Gulf of Guinea}

136 The surface layer of the eastern tropical Atlantic is composed of warm and poorly salted

137 Tropical Surface Water (TSW; Fig. 3). The low salinity of TSW is largely attributable to 
138 intense river runoff and rainfall in the Gulf of Guinea (Fig. 3A). At about $70 \mathrm{~m}$ depth, the

139 base of TSW is marked by a broad salinity maximum in the temperature range $17-22{ }^{\circ} \mathrm{C}$ (Fig.

140 3B), which corresponds to Subtropical Underwater (STUW). Below STUW, the South

141 Atlantic Central Water masses (SACW) extend up to 500 m depth, characterized by a nearly

142 linear temperature - salinity relationships (Fig. 3B). The water mass below SACW

143 corresponds to colder $\left(\sim 5^{\circ} \mathrm{C}\right)$ and fresher (salinity $\left.\sim 34.5\right)$ Antarctic Intermediate Water

144 (AAIW), centered at about $800 \mathrm{~m}$ depth. Finally, the deeper water masses in the study area

145 are dominated by southward-flowing North Atlantic Deep Water (NADW). Circulation

146 patterns of the upper water masses are quite complex in the Niger Delta area (Fig. 1). Surface

147 waters are transported eastward by the Guinea Current (GC), while circulation of water

148 masses below $100 \mathrm{~m}$ is dominated by the westward-flowing Northern South Equatorial

149 Current (nSEC).

150

\section{3 - Sampling and methods}

152 Samples were collected during previous expeditions to the Niger Delta aboard N/O Atalante

153 (NERIS project, 2004) and N/O Pourquoi Pas? (ERIG-3D project, 2008). All seawater samples were collected during the ERIG-3D cruise using 8 l PVC-bottles mounted on a CTDrosette assembly. For determination of methane concentrations, aliquots of $125 \mathrm{ml}$ were collected in glass bulbs on board, and stored in a cold room to await transportation to the

157 laboratory in Brest. Then, methane was analysed using a chromatographic purge/trap

158 technique (Charlou and Donval, 1993; Charlou et al., 1998). For total dissolvable trace 159 element analyses (TDFe, TDMn, TDREE), a $60 \mathrm{ml}$ aliquot of non filtered seawater was 160 transferred into acid-cleaned polyethylene bottles, and acidified to $\sim \mathrm{pH} 2$ with ultra-pure 161 twice sub-boiled $\mathrm{HNO}_{3}$. For dissolved REE studies, $250 \mathrm{ml}$ seawater samples were filtered 162 through $0.45 \mu \mathrm{m}$ cellulose filters. After filtration, seawater samples were acidified to $\sim \mathrm{pH} 2$ 
with ultra-pure twice sub-boiled $\mathrm{HNO}_{3}$, prior to addition of Tm spike. The REE were then extracted from the filtered samples by ferric-hydroxide co-precipitation, after addition of $\mathrm{NH}_{4}$ (Bayon et al., 2011). For Nd isotope measurements, between $\sim 5$ and $20 \mathrm{l}$ of seawater were filtered and acidified to $\sim \mathrm{pH}$ 2. At Brest, Nd and other REE were then pre-concentrated by ferric-hydroxide co-precipitation, followed by purification using cation exchange (AG 50WX8) and Ln-resin columns.

A series of sub-surface sediment samples recovered by either piston or gravity coring near the hydrocast stations were also analysed in this study (see core location in Fig. 2). Pore waters were extracted from bulk sediments on board by centrifugation and filtered $(0.45 \mu \mathrm{m})$ immediately. Upon availability, $\sim 3$ to $40 \mathrm{ml}$ aliquots of pore waters were processed for determination of REE concentrations, following the procedure described above (Bayon et al., 2011). Uncleaned foraminifera fractions (mainly Globigerinoides ruber) were analysed to gain additional information on the $\varepsilon_{\mathrm{Nd}}$ signature of bottom waters, as demonstrated recently by Roberts et al. (2010). Foraminifera fractions were cleaned in ultrasonic bath with ultra pure water, prior to dissolution using dilute $\mathrm{HNO}_{3}$ acid. The terrigenous fraction of every studied sediment sample was also analysed after removal of carbonate and Fe-oxyhydroxide phases from the bulk sediment (Bayon et al., 2002). In addition, the fine-grained $(<45 \mu \mathrm{m})$ fraction of each core-top sediment sample was leached (room $\mathrm{T}^{\circ} \mathrm{C}, 24 \mathrm{~h}$ ) using ultra-pure dilute $(0.05 \% \mathrm{v} / \mathrm{v})$ nitric solution (i.e. easily leachable fraction), in order to assess the potential contribution of sediment dissolution to the non-filtered seawater samples. The acid strenght of this dilute nitric solution exactly matches that of the solution $(\mathrm{pH} \sim 2$ ) in which non-filtered seawater samples were stored prior to analysis. Then, dilute $\mathrm{HNO}_{3}$ leachates were filtered $(0.45 \mu \mathrm{m})$ before processing for REE and $\mathrm{Nd}$ isotope measurements. Finally, two methane-derived carbonate concretions and authigenic gypsum were hand-picked from 
the Pockmark Field and Mud Volcano sediments, cleaned using ultra pure water, and analysed to provide direct information on the pore water $\varepsilon_{\mathrm{Nd}}$ signature at the studied cold seep

190 sites.

192 All measurements were made at the Pôle Spectrométrie Océan (PSO), Brest. Rare earth element, Fe and Mn concentrations were measured with an ELEMENT 2 ICP-SFMS. The REE were analysed with the low resolution mode to enhance sensitivity, but were corrected 195 for interferences following the procedure of Bayon et al. (2009). Rare earth element 196 concentrations were calculated using the Tm addition method (Barrat et al., 1996; Bayon et 197 al., 2009). Details on the applicability of this method for determining REE abundances in 198 seawater are given elsewhere (Bayon et al., 2011; Freslon et al., 2011). For Fe and Mn, the 199 ELEMENT2 was operated in medium resolution mode. Procedural blanks for Fe and Mn 200 corresponded to $\sim 1.5 \mathrm{nM}$ and $\sim 0.5 \mathrm{nM}$, respectively. Neodymium isotopic ratios were 201 determined by Neptune MC-ICP-MS. Analysis of the JNdi-1 standard during the analytical 202 session gave ${ }^{143} \mathrm{Nd} /{ }^{144} \mathrm{Nd}$ of $0.512115 \pm 0.000011$ (2 s.d., $\mathrm{n}=12$ ), which corresponds in epislon 203 notation (DePaolo and Wasserburg, 1976) to an $\varepsilon_{\mathrm{Nd}}$ value of $=-10.16 \pm 0.21$. Total 204 procedural blanks were less than $1 \mathrm{ng}$ for $\mathrm{Nd}$, which represented less than $6 \%$ of the mass of $205 \mathrm{Nd}$ in the measured fraction of seawater samples.

\section{4 - Results and Discussion}

\subsection{Depth profiles at the active venting sites: Pockmark Field and Mud Volcano sites}

The bottom water samples at the Pockmark Field (CTD-08) and Mud Volcano (CTD-06)

211 stations exhibit $\mathrm{CH}_{4}$ values with concentrations up to $~ 2000 \mathrm{nl} / \mathrm{l}$ and $\sim 330 \mathrm{nl} / \mathrm{l}$ respectively, 212 much higher than background seawater values (in the range $\sim 15$ and $40 \mathrm{nl} / \mathrm{l}$ ), which clearly 
213 indicate active fluid venting (Table 1). At these two sites, methane plumes rise up to about

$214100 \mathrm{~m}$ above the seafloor (Fig. 4). Iron and manganese oxyhydroxide precipitation typically

215 occurs above methane seeps at submarine hydrothermal systems (e.g. German et al., 1990),

216 but also on continental margins (Charlou et al., 2004), when Fe-rich vent fluids mixed with

217 high $\mathrm{pH}(\mathrm{pH} \sim 8)$ and oxygen-rich bottom waters. Similarly, here, the plumes at Pockmark

218 Field and Mud Volcano also exhibit distinctive anomalies for both TDMn ( up to 8 nmol/L;

219 Table 1) and TDFe (up to $50 \mathrm{nmol} / \mathrm{L}$ ), which could hence reflect the presence of Fe-Mn

220 oxyhydroxyde particulates. Alternatively, the occurence of Fe and Mn anomalies in non-

221 filtered seawater samples could also indicate partial dissolution of suspended particles

222 entrained within the plumes. High levels of TDREE concentrations were also determined in

223 the methane plumes at both sites (Table 1), with depth profiles for TDNd closely resembling

224 those for TDFe (Fig. 4). Interestingly, while TDNd concentrations are significantly enriched

225 in the methane plumes (up to $62 \mathrm{pmol} / \mathrm{kg}$ ), the dissolved $\mathrm{Nd}$ contents for the same samples are

226 much lower (around $22 \mathrm{pmol} / \mathrm{kg}$; Table 2, Fig. 5), and do not exhibit any significant

227 enrichment relative to the overlying water column (Fig. 5). Overall, these results suggest that

228 venting of methane-rich fluids at cold seeps does not lead to significant emission of dissolved

229 REE into the water column. Our data show however that fluid venting is accompanied by a

230 flux of REE associated with iron-rich particulate phases, which could indicate either co-

231 precipitation of Fe-Mn oxyhydroxides in bottom waters or re-suspension of local sediments.

233 4.2. Evidence for benthic fluxes at the Reference Site

234 At the Reference Site, the bottommost water sample (CTD03-B1) exhibits higher TDFe and

235 TDMn concentrations (i.e. the highest TDMn value measured during the course of this study;

$23610.3 \mathrm{nmol} / \mathrm{kg}$, Table 1) than the overlying water column (Fig. 4). In contrast with the

237 Pockmark Field and Mud Volcano sites, however, these anomalies are most probably due to 
238 diffusion from surface sediments at this location, rather than to active fluid venting.

239 Similarly, the same bottommost sample also displays the highest dissolved REE 240 concentrations determined in this study (e.g. [Nd] $27.9 \mathrm{pmol} / \mathrm{kg}$, Table 1). Taken together, 241 these results could suggest that benthic fluxes at the Reference Site (i.e. away from any active 242 fluid venting area) lead to diffusive emission of REE into bottom waters. Evidence that both 243 TDNd and dissolved Nd exhibit similar concentrations at this site, as shown in Fig. 5, 244 indicates however the absence of any significant Fe-oxyhydroxide co-precipitation or 245 sediment resuspension at this station.

\subsection{Deciphering REE provenance in the filtered and non-filtered seawater samples}

248 To gain further constraints on the origin of REE sources in the methane plumes, we 249 considered shale-normalised REE patterns for both non-filtered (TD data) and filtered 250 (dissolved concentrations) samples (Fig. 6), and compared them to data for pore waters (Table 3) and easily leachable sediment fractions (Table 4). For clarity, only REE patterns for selected seawater samples from the Pockmark Field and the Reference Site are shown in Fig. 6, but note that similar conclusions could be also drawn using samples from the Mud 254 Volcano.

256 At the Pockmark Field, filtered samples collected from within the plume (sample CTD08-B1 to -B8; Table 2) all display very similar seawater-like REE patterns (Fig. 6A), characterized 258 by a pronounced negative Ce-anomaly and progressively increasing shale-normalized values 259 from the light- (LREE) to the heavy-REE (HREE). These patterns are very similar to those 260 determined for the seawater samples at the Reference hydrocast station (Fig. 6B). In marked 261 contrast, non-filtered samples collected at the same water depths at the Pockmark Field show 
a larger range of REE patterns, with variable Ce-anomalies and various mid-REE (MREE) over LREE enrichments (Fig. 6A). In comparison, pore waters from sub-surface sediments at 264 the Mud Volcano and other active venting sites of the Niger Delta area exhibit REE concentrations about one order of magnitude higher than those for seawater samples (Table 3). These pore water samples display shale-normalized patterns characterized by a positive 267 Ce-anomaly and a MREE enrichment relative to LREE and HREE (Fig. 6A). This MREE268 bulge type pattern is a typical feature of anoxic pore waters in marine sediments, interpreted 269 as the consequence of the reduction of sedimentary Fe-oxyhydroxide phases during early diagenesis (Haley et al., 2004). Although we did not analyse any pore water sample from the

271 Pockmark Field area, the carbonate concretion collected from core ER-CS-38 also displays a 272 similar REE pattern (Table 4, pattern not shown here), which suggests that it was formed 273 from fluids having similar REE signature (Rongemaille et al., 2011). Here, the evidence that 274 filtered samples collected from within the methane plume exhibit seawater-like REE patterns 275 that are well distinct from those for local sub-surface pore waters provides strong support that 276 active venting at these seeps does not represent any substantial source of dissolved REE to 277 bottom waters.

279 As discussed earlier, one explanation accounting for the TDFe, TDMn and TDREE anomalies 280 at both the Pockmark Field and Mud Volcano was that they were due to co-precipitation of 281 Fe-Mn oxyhydroxide phases in bottom waters above venting sites. If this was the case, 282 however, one would expect the filtered samples collected from the methane plumes to have 283 inherited, at least partly, the distinctive REE signature of pore waters. Instead, it is more 284 likely that these anomalies indicate partial dissolution of resuspended particles entrained 285 within the methane plumes. This hypothesis can be demonstrated using simple mass balance 286 calculations with REE concentrations for typical bottom water (e.g., filtered sample CTD08- 
B3) and the easily leachable fractions of core-top sediments (Table 4). Comparatively, the

288 REE concentrations determined in the dilute nitric leachates are much higher (i.e., about a 289 factor $10^{8}$ ) than seawater values. The leaching experiments with dilute $\mathrm{HNO}_{3}$ led to the 290 extraction of about $20 \mathrm{wt} \%$ of the initial mass of sediment. This implies that the presence of 291 even a very small amount of suspended particles in any of our non-filtered seawater samples 292 could have a significant impact on its REE composition. In Fig. 6C, we show that the REE 293 patterns for non-filtered samples from within the plume at the Pockmark Field can be generated by partial dissolution of sediments in seawater samples having total suspended matter loadings (TSM) of about 0.1 to $0.2 \mathrm{mg} / \mathrm{l}$. For comparison, this range of values is similar to the maxima TSM concentrations measured in hydrothermal plumes (i.e., up to 90 $\mu g / l ;$ Trocine and Trefry, 1988; Feely et al., 1994).

Interestingly, the shale-normalized REE patterns of these easily leachable sediment fractions are also characterized by a strong positive Ce-anomaly and a marked MREE enrichment (see the theoretical pattern for a non-filtered seawater sample with TSM of $1 \mathrm{mg} / \mathrm{l}$, Fig. 6C). As mentionned earlier, this pattern is typical of sedimentary Fe-oxyhydroxide phases (e.g., 303 Bayon et al., 2004). This suggests that a significant fraction of the REE extracted from our core-top sediments during our leaching experiments is derived from the dissolution of REErich Fe-oxyhydroxide phases. By analogy, it is very likely that the measured TDFe, TDMn and TDREE anomalies determined in the non-filtered seawater samples above venting sites were due to dissolution of Fe-Mn oxyhydroxide phases associated to suspended particles 308 within the plumes. Taking a further logical step, we propose that Fe-oxyhydroxide co309 precipitation in the near surface environment is responsible for the net removal of pore water 310 REE in sub-surface sediments at active vent sites, thereby leading to the absence of 311 significant emission of dissolved REE into bottom waters. 
313 Interestingly, careful examination of the vertical profiles at both Pockmark Field and Mud

314 Volcano sites shows that dissolved $\mathrm{Nd}$ concentrations are actually slightly depleted in 315 methane plumes relative to the overlying water column (Fig. 5). By analogy with what was 316 shown at hydrothermal systems (e.g. Michard et al., 1983; German et al., 1990; Sherrell et al., 317 1999; Edmonds and German, 2004), this could suggest that additional scavenging of seawater 318 REE take place within the plume, perhaps through continuous adsorption onto Fe-Mn oxyhydroxide phases or any other suspended particulates. Considering the Nd concentrations measured at these two sites (Table 2), one can calculate that Fe-rich particles within the

321 plumes can incorporate up to 7\% of the dissolved REE content of ambient seawater. 322 Importantly, this also suggests that fluid seepage at cold seeps could act as a net sink in the 323 global ocean budget of the REE.

\subsection{Nd isotope constraints on processes controlling dissolved REE profiles in the Gulf of}

\section{Guinea}

327 Neodymium isotopic measurements provide further constraints on the processes controlling 328 the distribution of dissolved REE at the studied CTD hydrocast stations. The Nd isotope 329 ratios measured in this study encompass a large range of $\varepsilon_{\mathrm{Nd}}$ values from about -10.7 to -15.7 330 (Table 2). Surface waters (TSW) exhibit $\varepsilon_{\text {Nd }}$ values of $\sim-12.5$ (CTD08-B13/14, 57m depth), 331 while the underlying subtropical underwater waters (STUW) are characterized by unradiogenic values ( -15.7; CTD3-B13/14, 60-180m depth). At the transition between South Atlantic central waters and Antarctic Intermediate water, values are centered around

334 12.5, with the exception of one sample ( -10.7; CTD06-B10/12, 460-500m depth,). The core 335 of AAIW displays lower $\varepsilon_{\mathrm{Nd}}$ values ( -13.3; CTD03-B9/10, 990-1190m depth), while 
336 NADW at the Reference Site is characterized by $\varepsilon_{\mathrm{Nd}}$ of $\sim-12.5$. Note that the $\varepsilon_{\mathrm{Nd}}$ values for 337 the uncleaned foraminifera separates from core-top sediments at the Pockmark Field and 338 Reference sites (Table 5; taken as a indirect measurement of the Nd isotope composition of 339 bottom waters; Roberts and al., 2010) are also in very good agreement with the $\varepsilon_{\mathrm{Nd}}$ signature 340 determined for deep waters at these sites. Clearly, the large $\varepsilon_{\mathrm{Nd}}$ variability in the Niger Delta 341 water column indicates various sources of dissolved $\mathrm{Nd}$. Below, we investigate several 342 possible mechanisms (i.e. isotopic exchange at cold seeps, sediment dissolution, lateral 343 advection), which could account for the vertical distribution of Nd isotopes at the three CTD 344 hydrocast stations.

First, although there are clear evidence for a net removal of REE at cold seeps (see previous section), isotopic exchange processes between methane-rich fluids and/or associated particles and seawater could possibly affect the Nd isotopic composition of the Gulf of Guinea bottom waters. To test this hypothesis, we measured the $\mathrm{Nd}$ isotopic composition of cold seep carbonate concretions and/or authigenic gypsum from sediments at the Mud Volcano and Pockmark Field, to estimate the $\varepsilon_{\mathrm{Nd}}$ signature of fluids expelled at these sites. Authigenic gypsum typically forms in reduced sediments after opening of the core sections, as a result of the oxidation of sulfides to sulfate. During precipitation, it probably incorporates a number of dissolved trace element (including REE) from pore waters, and can hence be used to infer the Nd isotopic composition of surrounding pore waters. At the Pockmark Field, the authigenic carbonate concretion exhibits a $\varepsilon_{\mathrm{Nd}}$ value $(-12.0 \pm 0.3)$ similar to the measured bottom water signature $(-12.1 \pm 0.6)$, but slightly lower than that for uncleaned foraminifera $(-12.5 \pm 0.1)$. At the Mud Volcano, however, the obtained $\varepsilon_{\mathrm{Nd}}$ values for authigenic minerals $\left(\varepsilon_{\mathrm{Nd}}\right.$ from $\sim$ 11.5 to $-11.3 \pm 0.2$; Table 3 ) differ significantly from that of local bottom waters $(-12.3 \pm 0.4)$. 
In agreement with our REE data, this suggests that fluid seepage at cold seeps do not modify significantly the Nd isotopic composition of bottom water masses at ocean margins.

Second, as suggested previously for other areas of high sedimentary inputs (Nozaki and Alibo, 2002; Tachikawa et al., 1999), partial dissolution of detrital particles settling through the water column could play a significant role in controlling the vertical distribution of dissolved REE. In the study area, however, both detrital sediments (average $\varepsilon_{\mathrm{Nd}} \sim-11.6 \pm$ 0.3) and easily leachable fractions (i.e., dilute $\mathrm{HNO}_{3}$ leachates; average $-11.3 \pm 0.3$ ) are characterized by a Nd isotopic signature significantly different from the seawater $\varepsilon_{\mathrm{Nd}}$ values throughout the water column (Fig. 4). Clearly, this shows that interaction between seawater and settling particles in this part of the Gulf of Guinea is unlikely to play any significant role in the REE oceanic cycling.

Finally, based on these results, our preferred explanation is that lateral advection (i.e. ocean circulation patterns) controls the observed vertical distribution of Nd isotope ratios at our CTD hydrocast stations. This hypothesis is supported by evidence that 1 ) each water mass is characterized by a well-distinct $\varepsilon_{\mathrm{Nd}}$ signature (Fig. 4), and 2) that the composite vertical

377 profile for $\varepsilon_{\mathrm{Nd}}$ closely resembles those for dissolved $\mathrm{Nd}$ concentrations (Fig. 4). In addition, 378 lateral advection would explain well why the $\mathrm{Nd}$ isotopic composition for STUW is very 379 unradiogenic $\left(\varepsilon_{\mathrm{Nd}} \sim-15.7 \pm 0.5\right)$. In the Gulf of Guinea, the STUW is transported by the 380 northern Equatorial current (Fig. 1), which mainly receives its water from the northward 381 flowing Equatorial undercurrent (EUC). The main rivers draining western equatorial Africa are delivering to the Atlantic Ocean suspended and/or dissolved loads characterized by very 383 low $\varepsilon_{\mathrm{Nd}}$ values (Congo -16; Allègre et al ., 1996; Bayon et al., 2009; Ogooué -24; G. 
Bayon, unpubl. data; Ntem -28; Weldeab et al., 2011). Therefore, if any significant

385 sediment/seawater interaction takes place at the western African ocean margin, one would accordingly expect the water masses transported by the EUC to acquire a unradiogenic $\varepsilon_{\mathrm{Nd}}$ signature, thereby explaining the low value measured in this study for STUW.

\subsection{Implications for the marine Nd cycle at continental margins}

As already mentioned in the Introduction, there are numerous evidence that the Nd isotopic signature of water masses can be modified on ocean margins (e.g. Lacan and Jeandel, 2005; Andersson et al., 2008; Amakawa et al., 2009), which suggest that sediment-seawater interaction at margins could represent a major component of the oceanic $\mathrm{Nd}$ cycle (e.g. Arsouze et al., 2009). Similarly, our Nd isotope seawater data for the Niger Delta margin also provide another evidence for 'boundary exchange' (see discussion above for STUW). In addition, the $\varepsilon_{\mathrm{Nd}}$ value determined for AAIW in our study area (between $-13.3 \pm 0.3$ and -12.4 \pm 0.4 ; Table 2) markedly differs from that reported for the same water mass at a nearby station, in the western part of the Gulf of Guinea (-11.5 \pm 0.3 ; Rickli et al., 2010). Similarly to what was proposed above for explaining the unradiogenic signature of STUW, the lower $\varepsilon_{\mathrm{Nd}}$ value measured here for AAIW most probably indicate sediment/seawater interactions at 401 the western equatorial African margin (Fig. 1). As discussed above, venting of reduced fluids 402 at cold seeps and dissolution of settling lithogenic particles both are unlikely to account for the observed differences. Alternatively, one possible explanation accounting for the shift of AAIW towards unradiogenic $\varepsilon_{\mathrm{Nd}}$ signature during its northward flow trajectory in this part of 405 the Gulf of Guinea would be that it was modified by diffusive benthic fluxes from organic406 rich sediments. 
408 Of course, we cannot rule out the possibility that in certain parts of the ocean, dissolution of

409 settling particles, for example, represents the dominant input of dissolved REE to the ocean.

410 Additional case studies would also be clearly needed to confirm the results presented here.

411 However, our data suggest that diffusive benthic fluxes from suboxic settings could represent

412 a substantial source of dissolved REE in the Gulf of Guinea. Earlier works already suggested

413 that diffusion from marine sediments was likely to play a significant role in the marine REE

414 cycle (e.g. Elderfield and Greaves, 1982). Although only few studies have examined the

415 distribution of REE in interstitial waters of marine sediments (Elderfield and Sholkovitz,

416 1987; Sholkovitz et al., 1989; Haley et al., 2004), these works clearly showed that REE were

417 significantly enriched in pore waters relative to bottom waters, in agreement with the data

418 presented here, establishing strong chemical gradients in the near surface environment.

419 Certainly, the relatively high REE contents in pore waters are derived from the degradation of

420 potentially REE-rich phases (e.g., organic material, Fe-Mn oxyhydroxides) during early

421 diagenetic processes (e.g. Haley et al., 2004), which, in turn, is closely related to the amount

422 of organic compounds accumulated in subsurface sediments. As a first approximation,

423 therefore, one could suggest that the benthic fluxes of dissolved REE from marine sediments

424 are positively correlated with organic material contents. Because accumulation rates of

425 organic material in marine sediments are typically much higher on continental margins than in

426 open ocean settings, this would be entirely consistent with the proposed hypothesis that

427 sediment-seawater interactions at margins (in this case, benthic fluxes from suboxic

428 sediments) may represent a important component of the marine Nd cycle.

\section{4 - Conclusion}

431 The data presented here indicate that seepage of methane-rich fluids on continental margins 432 do not represent a source of dissolved Nd to the ocean. Similarly to what was previously 
433 reported at submarine hydrothermal systems, it is very likely that Fe-Mn oxyhydroxide 434 precipitation in sub-surface sediments leads to quantitative removal of dissolved REE 435 whenever reduced (anoxic) fluids are emitted at cold seeps, acting possibly as a net sink for 436 REE in the ocean. In contrast, we suggest that diffusive benthic fluxes from suboxic surface 437 sediments could play a significant role in the marine $\mathrm{Nd}$ cycle, at least at the Niger Delta 438 margin.

Acknowledgments

We thank the Captains, the officers and crews of R/V Pourquoi Pas?, and members of the ERIG-3D scientific parties for their assistance at sea. We are very grateful to the three anonymous reviewers for their thoughtful and constructive comments, and thanks G.M. Henderson for editorial handling. This work was funded by IFREMER and TOTAL via the ERIG-3D project.

\section{References}

449 Allègre, C.J., Dupré, B., Negrel, P., Gaillardet, J., 1996. Sr-Nd-Pb isotope systematics in 450 Amazon and Congo River systems: Constraints about erosion processes. Chem. Geol. 131, $45193-112$.

452 Amakawa, H., Alibo, D.S., Nozaki, Y., 2000. Nd isotopic composition and REE pattern in the 453 surface waters of the eastern Indian Ocean and its adjacent seas. Geochim. Cosmochim. $454 \quad$ Acta 64, 1715-1727.

455 Amakawa, H., Sasaki, K., Ebihara, M., 2009. Nd isotopic composition in the central North $456 \quad$ Pacific. Geochim. Cosmochim. Acta 73, 4705-4719. 
Andersson, P.S., Porcelli, D., Frank, M., Bjork, G., Dahlqvist, R., Gustafsson, O., 2008. Neodymium isotopes in seawater from the Barents Sea and Fram Strait Arctic-Atlantic gateways. Geochim. Cosmochim. Acta 72, 2854-2867.

Arsouze, T., Dutay, J.-C., Lacan, F., Jeandel, C., 2009. Reconstructing the Nd oceanic cycle using a coupled dynamical - biogeochemical model. Biogeosciences, 6, 5549-5588.

Arsouze, T., Dutay, J.-C., Lacan, F., Jeandel, C., 2007. Modeling the neodymium isotopic composition with a global ocean general circulation model. Chem. Geol. 239, 156-164.

Barrat, J.A., Keller, F., Amossé, J., Taylor, R.N., Nesbitt, R.W., Hirata, T., 1996.

Determination of rare earth element in sixteen silicate reference samples by ICP-MS after Tm addition and ion exchange separation. Geostand. Newslett. 20, 133-139.

Bayon, G., German, C.R., Boella, R.M. Milton, J.A. Taylor, R.N. Nesbitt, R.W., 2002. Sr and $\mathrm{Nd}$ isotope analyses in paleoceanography: the separation of both detrital and Fe-Mn fractions from marine sediments by sequential leaching. Chem. Geol. 187, 179-199.

Bayon, G., German, C.R., Burton, K.W., Nesbitt, R.W., Rogers, N., 2004. Sedimentary FeMn oxyhydroxides as paleoceanographic archives and the role of aeolian flux in regulating oceanic dissolved REE. Earth Planet. Sci. Lett. 224, 477-492.

Bayon, G., Pierre, C., Etoubleau, J., Voisset, M., Cauquil, E., Marsset, T., Sultan, N., Le Drezen, E., Fouquet, Y., 2007. Sr/Ca and $\mathrm{Mg} / \mathrm{Ca}$ ratios in Niger Delta sediments: Implications for authigenic carbonate genesis in cold seep environments. Mar. Geol. 241, 93-109.

Bayon, G., Barrat, J.-A., Etoubleau, J., Benoit, M., Bollinger, C., Révillon, S., 2009a. Determination of rare earth elements, Sc, Y, Zr, Ba, Hf and Th in geological samples by ICP-MS after Tm addition and alkaline fusion. Geostand. Geoanal. Res. 33, 51-62. 
Bayon, G., Burton, K.W., Soulet, G., Vigier, N., Dennielou, B., Etoubleau, J., Ponzevera, E., German, C.R., Nesbitt, R.W., 2009b. Hf and Nd isotopes in marine sediments: Constraints on global silicate weathering. Earth Planet. Sci. Lett. 277, 318-326.

Bayon, G., Birot, D., Bollinger, C., Barrat, J.A., 2011. Multi-elemental analyses of trace metals in seawater by ICP-SFMS after Tm addition and iron co-precipitation. Geostand. Geoanal. Res. 35, 145-153.

Bertram, C.J., Elderfield, H., 1993. The geochemical balance of the rare earth elements and neodymium isotopes in the oceans, Geochim. Cosmochim. Acta 57, 1957-1986.

Brooks, J.M., Anderson, A.L., Sassen, R., MacDonald, I.R., Kennicutt, II M.C., Guinasso Jr., N.L., 1994. Hydrate occurrences in shallow subsurface cores from continental slope sediments. In: Annals of the New York Academy of Sciences 715, 381-391.

Castellini, D.G., Dickens, G.R., Snyder, G.T., Ruppel, C.D., 2006. Barium cycling in shallow sediment above active mud volcanoes in the Gulf of Mexico. Chem. Geol. 226, 1-30.

Charlou, J.L., Donval, J.P., 1993. Hydrothermal methane venting between $12^{\circ} \mathrm{N}$ and $26^{\circ} \mathrm{N}$ along the Mid-Atlantic Ridge. J. Geophys. Res. 98, 9625-9642.

Charlou, J.L., Fouquet, Y., Bougault, H., Donval, J.P., Etoubleau, J., Jean-Baptiste, P., Dapoigny, A., Appriou, P., Rona, P.A., 1998. Intense CH4 plumes generated by serpentinization of ultramafic rocks at the intersection of the $15^{\circ} 20^{\prime} \mathrm{N}$ fracture zone and the Mid-Atlantic Ridge. Geochim. Cosmochim. Acta 62, 2323-2333.

Charlou, J.L., Donval, J.P., Fouquet, Y., Ondreas, H., Knoery, J., Cochonat, P., Levaché, D., Poirier, Y., Jean-Baptiste, P., Fourré, E., Chazallon, B., The ZAIROV Leg 2 Scientific Party, 2004. Physical and chemical characterization of gas hydrates and associated methane plumes in the Congo-Angola Basin. Chem. Geol. 205, 405-425. 
DePaolo, D.J., Wasserburg, G.J., 1976. Nd isotopic variations and petrogenetic models. Geophys. Res. Lett. 3, 249-252.

507

508

Edmonds, H.N., German, C.R., 2004. Particle geochemistry in the Rainbow hydrothermal plume, Mid-Atlantic Ridge. Geochim. Cosmochim. Acta 68, 759-772.

Elderfield, H., Greaves, M.J., 1982. The rare-earth elements in sea-water. Nature 296, 214219.

Elderfield, H., Sholkovitz, E.R., 1987. Rare earth elements in the pore waters of reducing nearshore sediments. Earth Planet. Sci. Lett. 82, 280-288.

Elderfield, H., UpstillGoddard, R., Sholkovitz, E.R., 1990. The rare-earth elements in rivers, estuaries, and coastal seas and their significance to the composition of ocean waters. Geochim. Cosmochim. Acta 54, 971-991.

Feely, R.A., Gendron, J.F., Baker, E.T., Lebon, G.T., 1994. Hydrothermal plumes along the East Pacific Rise, $8^{\circ} 40^{\prime}$ to $11^{\circ} 50^{\prime} \mathrm{N}$ - particle composition and distribution. Earth Planet. Sci. Lett. 128, 19-36.

Frank, M., 2002. Radiogenic isotopes: tracers of past ocean circulation and erosional input. Rev. Geophys. 40, doi :10.1029/2000RG000094.

Freslon, N., Bayon, G., Birot, D., Bollinger, C., Barrat, J.A., 2011. Determination of rare earth elements and other trace elements (Y, Mn, Co, Cr) in seawater using Tm addition and $\mathrm{Mg}(\mathrm{OH})_{2}$ co-precipitation. Talanta, 85, 582-587.

Froelich, P.N., Klinkhammer, G.P., Bender, M.L., Luedtke, N.A., Heath, G.R., Cullen, D., Dauphin, P., Hammond, D. and Hartman, B., 1979. Early oxidation of organic matter in pelagic sediments of the eastern equatorial Atlantic - suboxic diagenis. Geochim. Cosmochim. Acta 43, 1075-1090.

German, C.R., Elderfield, H., 1990. Rare earth elements in the NW Indian Ocean. Geochim. Cosmochim. Acta 54, 1929-1940. 
German, C.R., Klinkhammer, G.P., Edmond, J.M., Mitra, A., Elderfield, H., 1990. Hydrothermal scavenging of rare earth elements in the ocean. Nature 345, 516-518.

Goldstein, S.J., Jacobsen, S.J., 1987. The Nd and Sr isotopic systematics of river-water dissolved material: Implications for the sources of Nd and Sr in seawater. Chem. Geol. 66, 245-272.

Goldstein, S.L., Hemming, S.R., 2003. Long-lived isotopic tracers in oceanography, paleoceanography, and ice-sheet dynamics. In: H. Elderfield, Editor, Treatise on Geochemistry, Elsevier, Oxford.

Greaves, M.J., Statham, P.J., Elderfield, H., 1994. Rare earth element mobilization from marine atmospheric dust into seawater. Mar. Chem. 46, 255-260.

Gutjahr, M., Frank, M., Stirling, C.H., Keigwin, L.D., Halliday, A.N., 2008. Tracing the Nd isotope evolution of North Atlantic deep and intermediate waters in the Western North Atlantic since the Last Glacial Maximum from Blake Ridge sediments. Earth Planet. Sci. Lett. 266, 61-77.

Haley, B.A., Klinkhammer, G.P., McManus, J., 2004. Rare earth elements in pore waters of marine sediments. Geochim. Cosmochim. Acta 68, 1265-1279.

Haley, B.A., Frank, M., Spielhagen, R.F., Eisenhauer, A., 2008. Influence of brine formation on Arctic Ocean circulation over the past 15 million years. Nature Geosci. 1, 68-72.

Halliday, A.N., Davidson, J.P., Holden, P., Owen, R.M., Olivarez, A.M., 1992. Metalliferous sediments and the scavenging residence time of Nd near hydrothermal vents. Geophys. Res. Lett. 19, 761-764.

Hovland, M., Judd, A.G., 1992. The global production of methane from shallow marine sources. Cont. Shelf Res. 12, 1209-1218. Japan Sea. Earth Planet. Sci. Lett. 244, 418-430. 
Jeandel, C., Thouron, D., Fieux, M., 1998. Concentrations and isotopic compositions of neodymium in the eastern Indian Ocean and Indonesian straits. Geochim. Cosmochim. Acta 62, 2597-2607.

Johannesson, K.H., Burdige, D.J., 2007. Balancing the global oceanic neodymium budget: evaluating the role of groundwater. Earth Planet. Sci. Lett. 253,129-142.

Judd, A.G., Hovland, M., Dimitrov, L.I., Gil, S.G., Jukes, V., 2002. The geological methane budget at continental margins and its influence of climate change. Geofluids 2, 109126.

Kopf, A., 2003. Global methane emission through mud volcanoes and its past and present impact on the Earth’s climate. Int. J. Earth Sci. (Geol. Rundsch.) 92, 806-816.

Lacan, F., Jeandel, C., 2001. Tracing Papua New Guinea imprint on the central Equatorial Pacific Ocean using neodymium isotopic compositions and Rare Earth Element patterns. Earth Planet. Sci. Lett. 186, 497-512.

Lacan, F., Jeandel, C., 2004a. Denmark Strait water circulation traced by heterogeneity in neodymium isotopic compositions. Deep-Sea Res. I 51, 71-82.

Lacan, F., Jeandel, C., 2004b. Neodymium isotopic composition and rare earth element concentrations in the deep and intermediate Nordic Seas: Constraints on the Iceland Scotland Overflow Water signature. Geochem. Geophys. Geosys. 5, Q11006.

Lacan, F., Jeandel, C., 2005. Neodymium isotopes as a new tool for quantifying exchange fluxes at the continent-ocean interface. Earth Planet. Sci. Lett. 232, 245-257.

Mascle, J., Bornhold, B.D., Renard, V. 1973. Diapiric structures off Niger delta. Amer. Assoc. Petrol. Geol. Bull. 57, 1672-1678.

McQuay, E.L., Torres, M.E., Collier, R.W., Huh, C.A., McManus, J., 2008. Contribution of cold seep barite to the barium geochemical budget of a marginal basin. Deep-Sea Res. I 55, 801-811. 
Michard, A., Albarède, F., Michard, G., Minster, J.F., Charlou J.L., 1983. Rare-earth elements and uranium in high-temperature solutions from East Pacific Rise hydrothermal vent field $\left(13^{\circ} \mathrm{N}\right)$. Nature $303,795-797$.

Milkov, A.V., Sassen, R., Apanasovich, T.V., Dadashev, F.G., 2003. Global gas flux from mud volcanoes: a significant source of fossil methane in the atmosphere and the ocean. Geophys. Res. Lett. 30, 1037, doi:10.1029/2002GL0165358.

Nozaki, Y., Alibo, D.S., 2003. Importance of vertical geochemical processes in controlling the oceanic profiles of dissolved rare earth elements in the northeastern Indian Ocean. Earth Planet. Sci. Lett. 205, 155-172.

Piotrowski, A.M., Goldstein, S.L., Hemming, S.R., Fairbanks, R.G., 2005. Temporal relationships of carbon cycling and ocean circulation at glacial boundaries. Science 307, 1933-1938.

Piotrowski, A.M., Banakar, V.K., Scrivner, A.E., Elderfield, H., Galy, A., Dennis, A., 2009. Indian Ocean circulation and productivity during the last glacial cycle. Earth Planet. Sci. Lett. 285, 179-189.

Puceat, E., Lecuyer, C., Reisberg, L., 2005. Neodymium isotope evolution of NW Tethyan upper ocean waters throughout the Cretaceous. Earth Planet. Sci. Lett. 236, 705-720.

\section{Original Research Article}

Rickli, J., Frank, M., Baker, A.R., Aciego, S., de Souza, G., Georg, R.B., Halliday, A.N., 2010. Hafnium and neodymium isotopes in surface waters of the eastern Atlantic Ocean: Implications for sources and inputs of trace metals to the ocean. Geochim. Cosmochim. Acta 74, 540-557.

Roberts, N.L., Piotrowski, A.M., McManus, J.F., Keigwin, L.D., 2010. Synchronous Deglacial Overturning and Water Mass Source Changes. Science 327, 75-78. 
604 Robinson, L.F., van de Flierdt, T., 2009. Southern Ocean evidence for reduced export of 605 North Atlantic Deep Water during Heinrich event 1. Geology 37, 195-198.

606 Rongemaille, E., Bayon, G., Pierre, C., Bollinger, C., Chu, N.C., Favreau, E., Fouquet, Y., 607 Riboulot, V., Voisset, M., 2011. Rare earth elements in cold seep carbonates from the 608 Niger Delta. Chem. Geol. 286, 196-206.

609 Rutberg, R.L., Hemming, S.R., Goldstein, S.L., 2000. Reduced North Atlantic Deep Water 610 flux to the glacial Southern Ocean inferred from neodymium isotope ratios. Nature 405, $611935-938$.

612 Scher, H.D., Martin, E.E., 2004. Circulation in the Southern Ocean during the Paleogene 613 inferred from neodymium isotopes. Earth Planet. Sci. Lett. 228, 391-405.

614 Sherrell, R.M., Field, M.P., Ravizza, G., 1999. Uptake and fractionation of rare earth 615 elements on hydrothermal plume particles at 9 degrees 45 ' N, East Pacific Rise. Geochim. 616 Cosmochim. Acta 63, 1709-1722.

617 Sholkovitz, E.R., 1995. The aquatic chemistry of rare earth elements in rivers and estuaries. 618 Aquat. Geochem. 1, 1-34.

619 Sholkovitz, E.R., Szymczak, R., 2000. The estuarine chemistry of rare earth elements: 620 comparison of the Amazon, Fly, Sepik and the Gulf of Papua systems. Earth Planet. Sci. 621 Lett. 179, 299-309.

622 Sholkovitz, E.R., Piepgras, D.J., Jacobsen, S.B., 1989. The pore water chemistry of rare earth 623 elements in Buzzards Bay sediments. Geochim. Cosmochim. Acta 53, 2847-2856.

624 Sholkovitz, E.R., Shaw, T.J., Schneider, D.L., 1992. The geochemistry of rare earth elements 625 in the seasonally anoxic water column and porewaters of Chesapeake Bay. Geochim. $626 \quad$ Cosmochim. Acta 56, 3389-3402.

627 Sholkovitz, E.R., Elderfield, H., Szymczak, R., Casey, K., 1999. Island weathering: river 628 sources of rare earth elements to the Western Pacific Ocean, Mar. Chem. 68, 39-57. 
Sultan, N., Voisset, M., Marsset, B., Marsset, T., Cauquil, E., Colliat, J.L., 2007. Potential role of compressional structures in generating submarine slope failures in the Niger Delta. Mar. Geol. 237, 169-190.

Sultan, N., Marsset, B., Ker, S., Marsset, T., Voisset, M., Vernant, A.M., Bayon, G., Cauquil, E., Adamy, J., Colliat, J.L., Drapeau, D., 2010. Hydrate dissolution as a potential mechanism for pockmark formation in the Niger delta. J. Geophys. Res 115, B08101.

Tachikawa, K., Jeandel, C., Roy-Barman, M., 1999. A new approach to Nd residence time: The role of atmospheric inputs. Earth Planet. Sci. Lett. 170, 433-446.

Tachikawa, K., Athias, V., Jeandel, C., 2003. Neodymium budget in the modern ocean and paleo-oceanographic implications. J. Geophys. Res. 108, 3254, doi :10.1029/1999JC000285.

Thomson, J., Higgs, N.C., Croudace, I.W., Colley, S. Hydes, D.J., 1993. Redox zonation of elements at an oxic/post-oxic boundary in deep-sea sediments. Geochim. Comochim. Acta 57, 579-595.

Torres, M.E., Bohrmann, G., Suess, E., 1996. Authigenic barites and fluxes of barium associated with fluid seeps in the Peru subduction zone. Earth Planet. Sci. Lett. 144, 469481.

Torres, M.E., McManus, J., Huh, C.A., 2002. Fluid seepage along the San Clemente Fault scarp: basin-wide impact on barium cycling. Earth Planet. Sci. Lett. 203, 181-194.

Trocine, R.P., Trefry, J.H., 1988. Distribution and chemistry of suspended particles from an active hydrothermal vent site on the Mid-Atlantic Ridge at $26^{\circ}$ N. Earth Planet. Sci. Lett. 88, 1-15.

van de Flierdt, T., Robinson, L.F., Adkins, J.F., Hemming, S.R., Goldstein, S.L., 2006. Temporal stability of the neodymium isotope signature of the Holocene to glacial North Atlantic. Paleoceanography 21, PA4102, doi: 10.1029/2006PA001294. 
661

662

663

664

665

666

667

668

669

670

671

672

673

674

675

676

677

678

Wallmann, K., Drews, M., Aloisi, G., Bohrmann, G., 2006. Methane discharge into the Black Sea and the global ocean via fluid flow through submarine mud volcanoes. Earth Planet. Sci. Lett. 248, 545-560.

Weldeab, S., Frank, M., Stichel, T., Haley, B., Sangen, M., 2011. Spatio-temporal evolution of the West African monsoon during the last deglaciation. Geophys. Res. Lett. 38, L13703, doi: 10.1029/2011GL047805.

\section{Figure captions}

Figure 1. Location of the three studied areas on the Niger Delta margin.

Location map showing the location of the study areas in the Gulf of Guinea. GC (Guinea Current) transports Tropical Surface Water (TSW) eastward in the Gulf of Guinea, whereas STUW (Subtropical Underwater) is advected by EUC (Equatorial Undercurrent) and NSEC (Northern Equatorial Current), respectively. NICC (Northern Intermediate Countercurrent) transports AAIW (Antarctic Intermediate Water) in the study area.

\section{Figure 2. Shaded bathymetric map for the Pockmark Field and the Mud Volcano areas.}

The location of the hydrocast stations and studied sediment cores is represented with large white circles and small red circles, respectively. A) The pockmark field area is characterized by the presence of large seafloor depressions with irregular shapes. B) The studied mud volcano (about $1 \mathrm{~km}$ wide) is composed of two distinct volcanic cones. Note the presence of a well-characterized depression at the periphery of the mud volcano.

\section{Figure 3. Hydrography at the Niger Delta margin.}


A) Salinity versus depth profiles and B) Temperature-Salinity diagram for the three studied hydrocast stations. The positions corresponding to the seawater samples analysed for $\mathrm{Nd}$ isotopes are shown in the Temperature-Salinity diagram. TSW: Tropical Surface Water; STUW: Subtropical Underwater; SACW: South Atlantic Central Water; AAIW: Antarctic Intermediate Water; NADW: North Atlantic Deep Water (NADW).

684

685

Figure 4. Depth profiles for methane, total dissolvable (TD) concentrations for Mn, Fe 686 and $\mathrm{Nd}$, dissolved $\mathrm{Nd}$ and $\varepsilon_{\mathrm{Nd}}$.

The methane, TDFe and TDMn concentrations show that active fluid venting occurs at the Pockmark Field and Mud volcano sites, with methane plumes rising up to about $100 \mathrm{~m}$ above the seafloor. Note that $\varepsilon_{\mathrm{Nd}}$ represents the relative deviation of the ${ }^{143} \mathrm{Nd} /{ }^{144} \mathrm{Nd}$ ratios of a sample, in parts per $10^{4}$, from that of the CHUR reference (CHondritic Uniform Reservoir): $\left[\left({ }^{143} \mathrm{Nd} /{ }^{144} \mathrm{Nd}\right)_{\text {sample }} /\left({ }^{143} \mathrm{Nd} /{ }^{144} \mathrm{Nd}\right)_{\mathrm{CHUR}}-1\right] \mathrm{X} 10^{4}$. The average Nd isotopic composition of leachable and detrital sediment fractions from Niger Delta core-top sediments is shown for comparison.

694

Figure 5. Relationships between total dissolvable (TD) and dissolved Nd concentrations in the bottom part of the water column.

The TDNd concentrations at the Pockmark Field and Mud volcano stations are significantly

698 enriched in the methane plumes. In contrast, dissolved Nd contents for the same samples are much lower, and do not exhibit any significant enrichment relative to the overlying water column. In the upper panel (Pockmark Field), note the small depletion in dissolved Nd at the bottom part of the plume relative to the upper part. 

and pore water samples.

A) At the Pockmark Field, filtered samples collected from within the plume exhibit similar shale-normalized patterns, while non-filtered samples collected at the same water depths show

707 a large range of REE patterns. B) At the Reference site, in contrast, both filtered and non708 filtered samples display similar REE patterns. C) Theoretical REE patterns generated by 709 partial dissolution of sediments in seawater samples having total suspended matter loadings 710 (TSM) of about $0.1,0.2$ and $1 \mathrm{mg} / \mathrm{l}$. The theoretical REE concentra are generated using 711 simple mass balance calculations with REE concentrations for typical bottom water (filtered 712 sample CTD08-B3) and the easily leachable fraction of core ER-CS-38. 


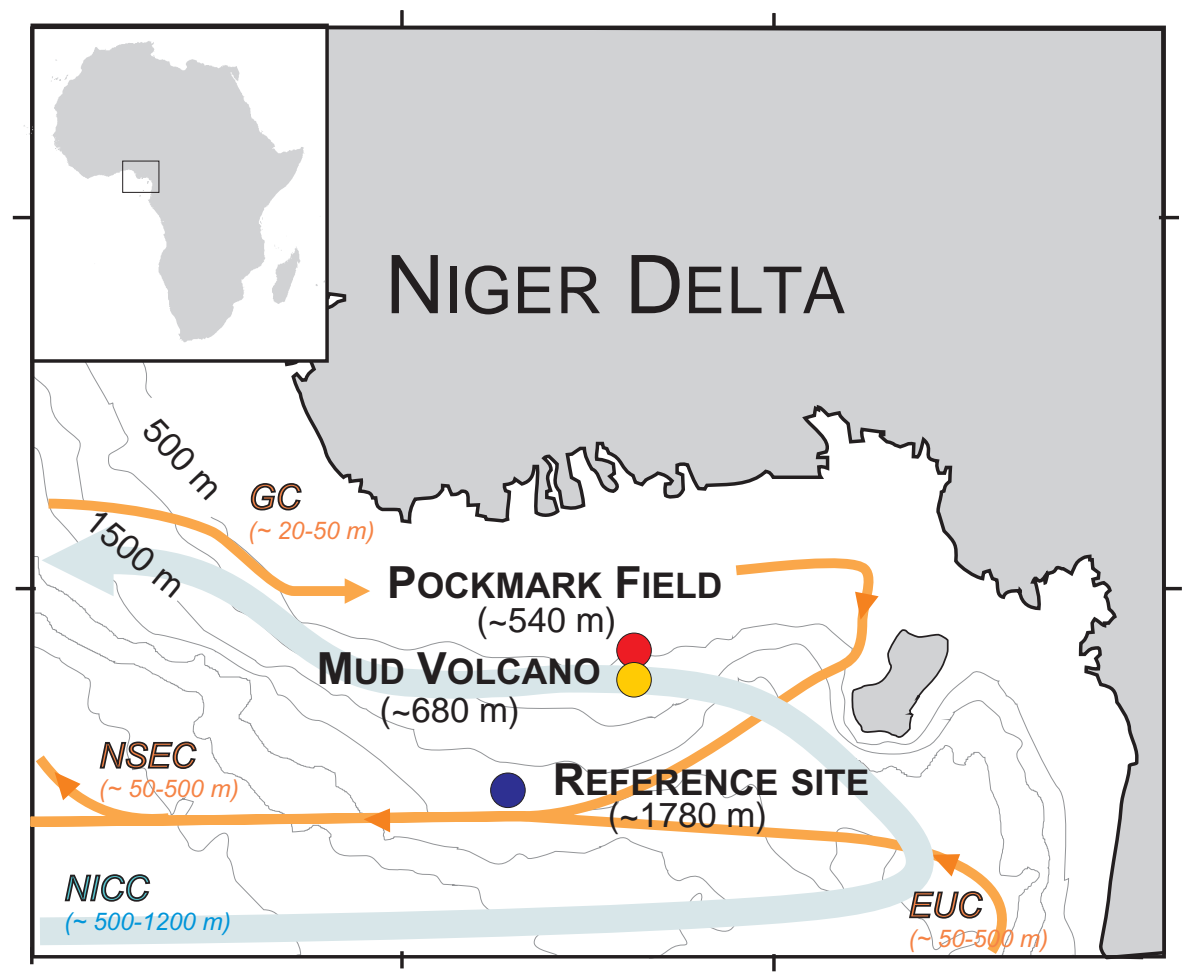

Fig. 1 


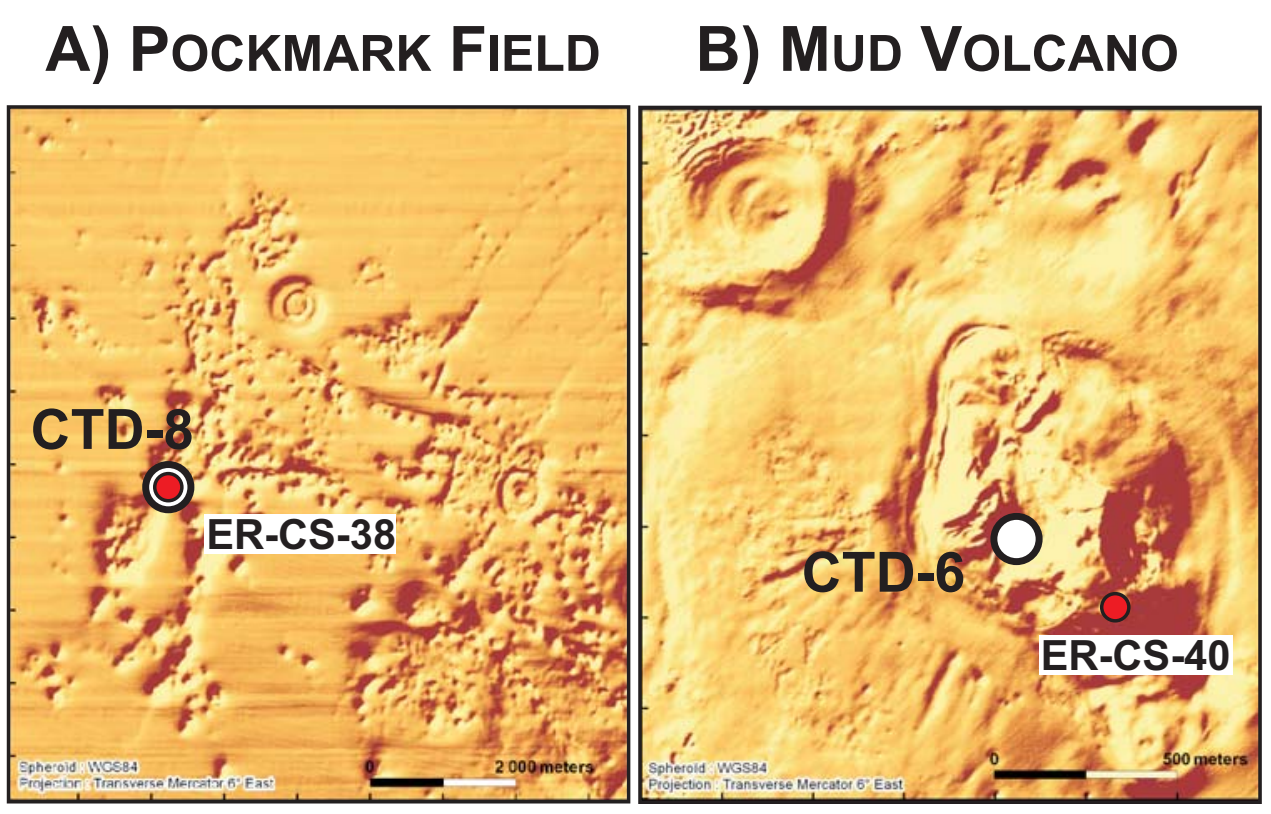

Fig. 2 

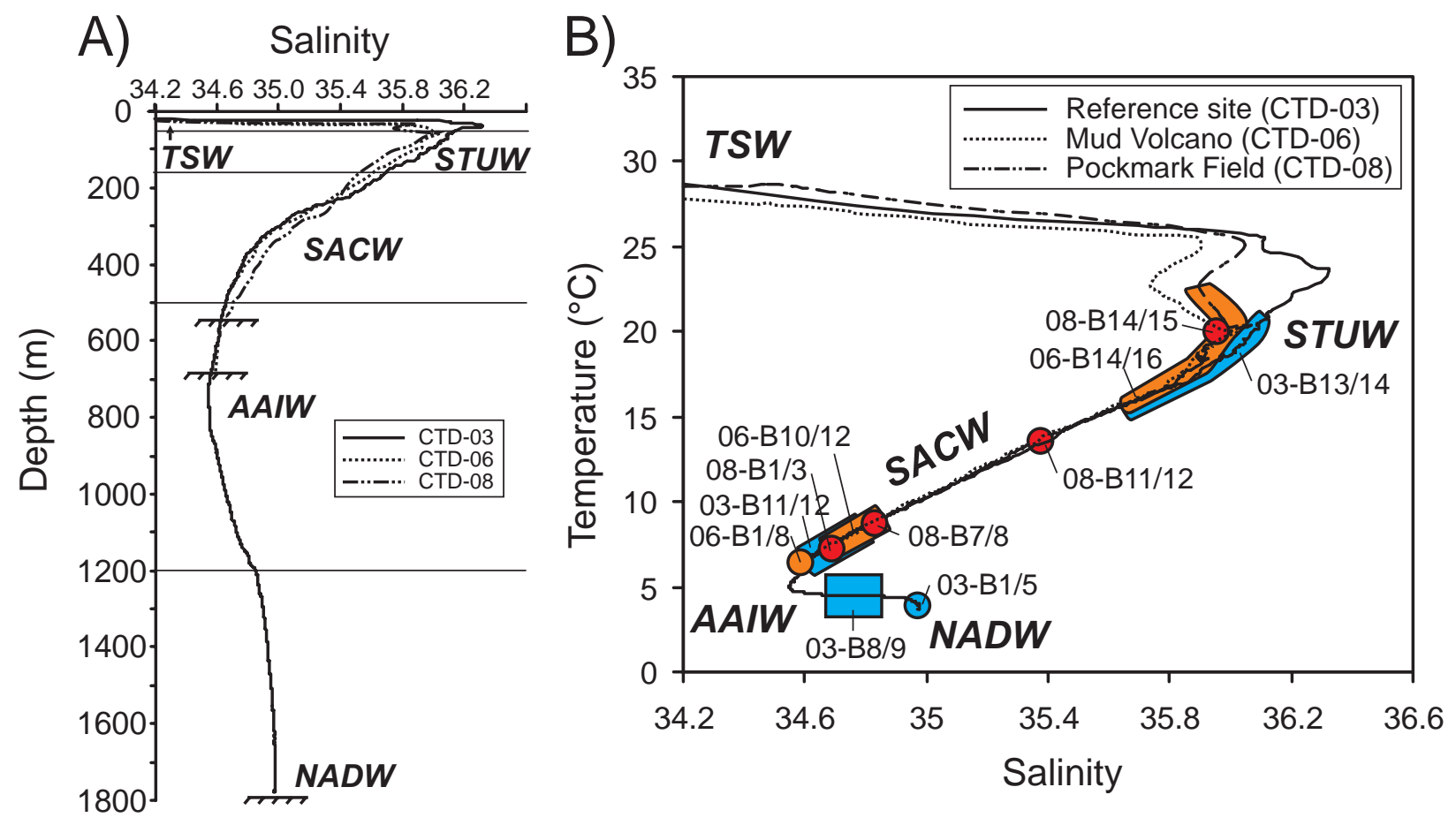


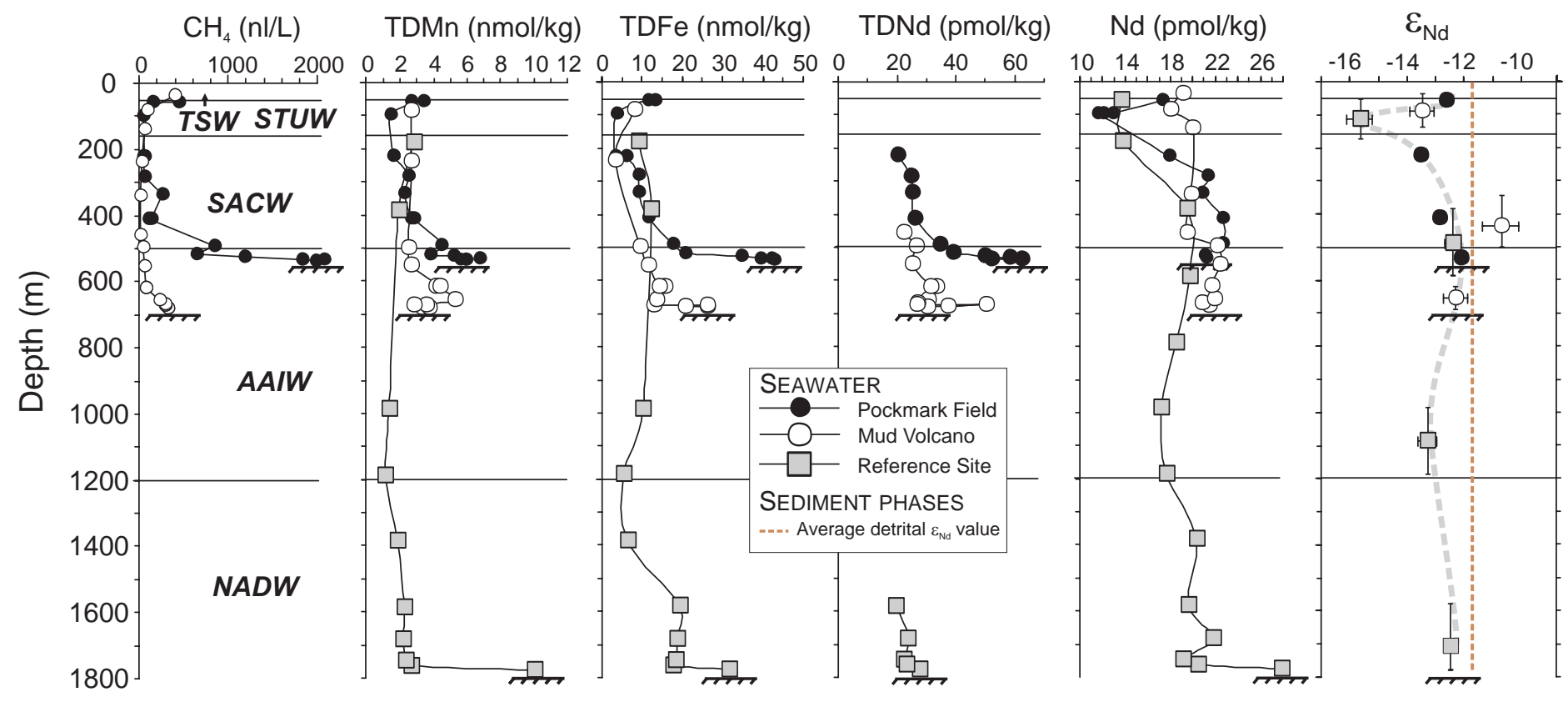

Fig. 4 


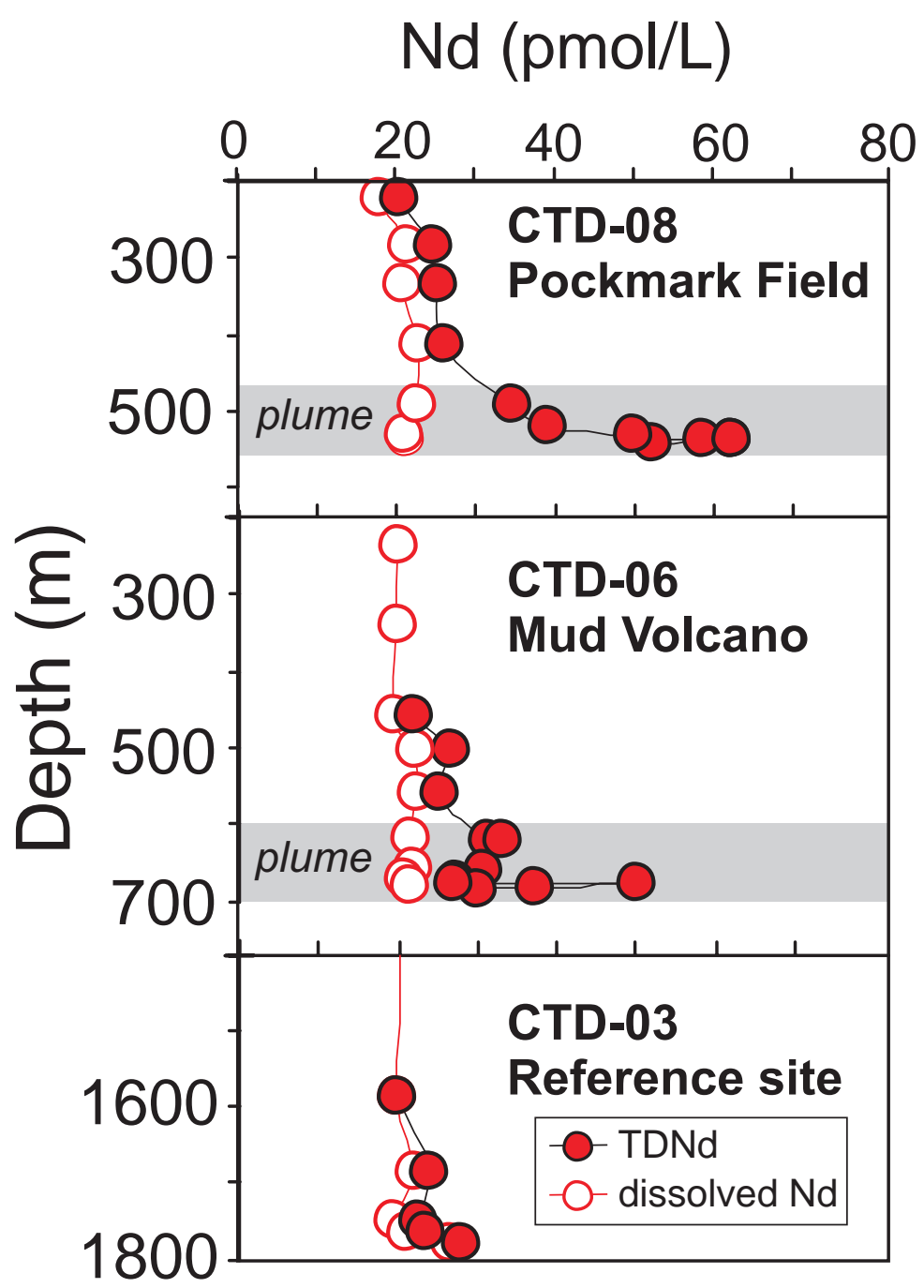

Fig. 5 

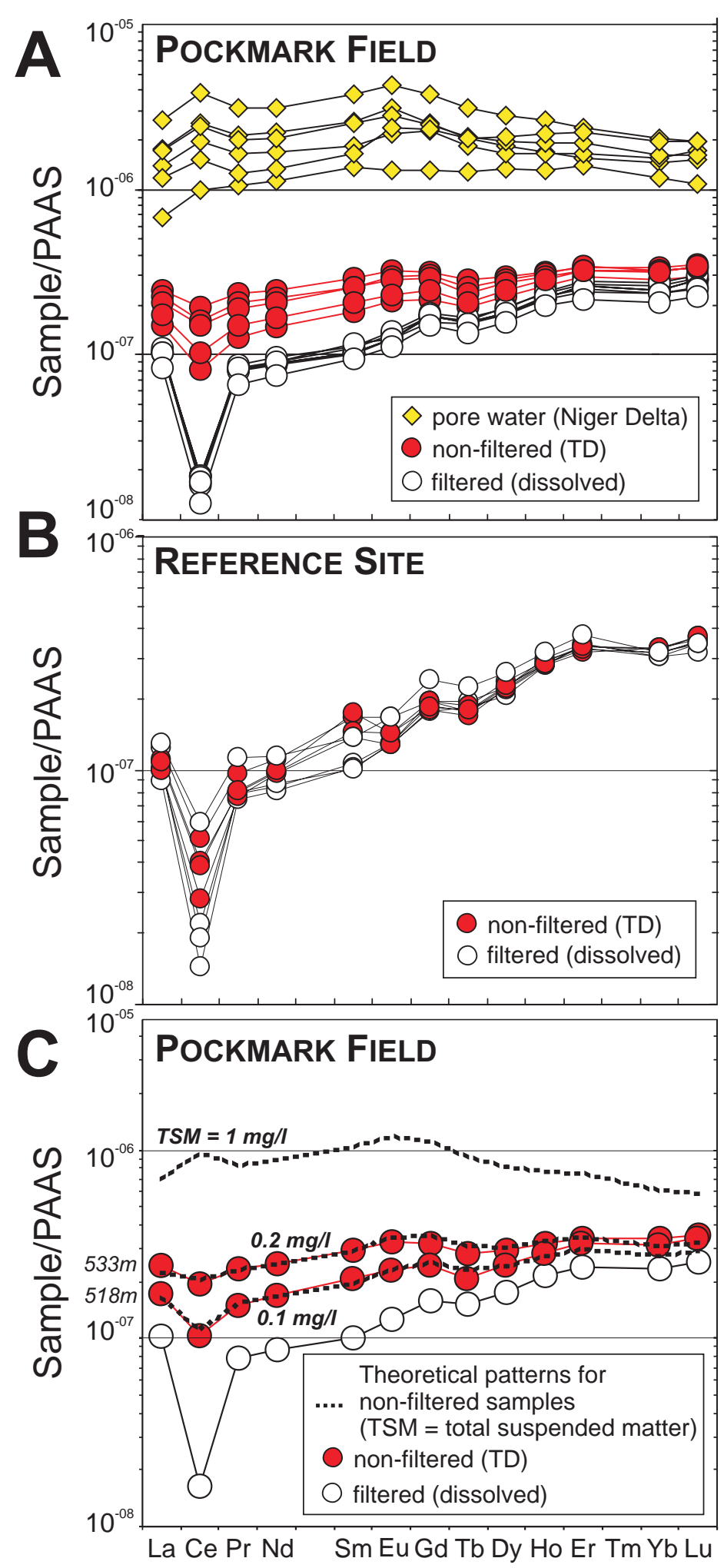

Fig. 6 
Tables

Table 1

$\mathrm{CH}_{4}$ and total dissolvable concentrations (Mn, Fe, REE) for Niger Delta seawater samples.

\begin{tabular}{|c|c|c|c|c|c|c|c|c|c|c|c|c|c|c|c|c|c|}
\hline \multirow[t]{2}{*}{ Sample } & Depth & $\mathrm{CH}_{4}$ & Mn & $\mathrm{Fe}$ & La & $\mathrm{Ce}$ & $\mathrm{Pr}$ & $\mathrm{Nd}$ & Sm & Eu & Gd & $\mathrm{Tb}$ & Dy & Ho & Er & $\mathrm{Yb}$ & Lu \\
\hline & $(\mathrm{m})$ & $(\mathrm{nl} / \mathrm{l})$ & $(\mathrm{nmol} / \mathrm{kg})$ & $(\mathrm{nmol} / \mathrm{kg})$ & \multicolumn{13}{|c|}{$(\mathrm{pmol} / \mathrm{kg})$} \\
\hline \multicolumn{18}{|c|}{ ER-CTDR-03 - Reference Area } \\
\hline CTD3-B1 & 1776 & & 10.28 & 30.23 & 34.72 & 29.02 & 6.08 & 26.41 & 6.44 & 1.21 & 3.00 & 0.92 & 6.97 & 1.77 & 5.82 & 5.37 & 0.93 \\
\hline CTD3-B2 & 1762 & & 2.41 & 18.46 & 30.70 & 23.23 & 5.06 & 23.24 & 5.56 & 1.03 & 2.81 & 0.87 & 6.41 & 1.69 & 5.48 & 5.42 & 0.91 \\
\hline CTD3-B3 & 1747 & & 2.07 & 19.09 & 27.38 & 16.12 & 4.84 & 22.56 & 5.39 & 0.92 & 2.04 & 0.84 & 6.43 & 1.72 & 5.60 & 5.22 & 0.88 \\
\hline CTD3-B4 & 1682 & & 1.82 & 19.24 & 30.11 & 22.31 & 5.14 & 23.62 & 6.55 & 1.03 & 2.36 & 0.89 & 6.63 & 1.72 & 5.79 & 5.43 & 0.92 \\
\hline CTD3-B6 & 1585 & & 1.92 & 19.93 & 27.58 & 14.86 & 4.46 & 19.80 & 4.60 & 1.00 & 5.13 & 0.80 & 6.26 & 1.65 & 5.69 & 5.37 & 0.91 \\
\hline CTD3-B7 & 1385 & & 1.46 & 8.97 & & & & & & & & & & & & & \\
\hline CTD3-B8 & 1187 & & 0.73 & 7.99 & & & & & & & & & & & & & \\
\hline CTD3-B9 & 987 & & 0.99 & 12.08 & & & & & & & & & & & & & \\
\hline CTD3-B12 & 385 & & 1.59 & 13.93 & & & & & & & & & & & & & \\
\hline CTD3-B13 & 181 & & 2.54 & 11.34 & & & & & & & & & & & & & \\
\hline \multicolumn{18}{|c|}{ ER-CTDR-06 - Mud Volcano } \\
\hline CTD6-B1 & 679 & 327 & 3.06 & 20.94 & 34.85 & 25.19 & 6.85 & 30.16 & 5.54 & 1.23 & 5.66 & 0.86 & 6.00 & 1.49 & 4.96 & 4.75 & 0.74 \\
\hline CTD6-B2 & 679 & 317 & 3.53 & 25.50 & 43.20 & 48.79 & 8.36 & 37.16 & 6.76 & 1.33 & 2.96 & 0.96 & 6.81 & 1.68 & 5.10 & 4.76 & 0.86 \\
\hline CTD6-B3 & 673 & 300 & 3.36 & 25.45 & 40.92 & 43.10 & 11.50 & 50.12 & 7.41 & 1.41 & 2.32 & 0.99 & 7.59 & 1.58 & 5.09 & 4.96 & 0.84 \\
\hline CTD6-B4 & 673 & 289 & 2.58 & 14.35 & 40.80 & 25.87 & 6.02 & 27.07 & 5.56 & 1.08 & 1.91 & 0.86 & 5.94 & 1.53 & 4.73 & 4.45 & 0.80 \\
\hline CTD6-B5 & 668 & 287 & 3.65 & & 33.39 & 26.69 & 6.17 & 27.04 & 5.88 & 1.20 & 1.95 & 0.82 & 5.63 & 1.47 & 4.80 & 4.71 & 0.79 \\
\hline CTD6-B6 & 658 & 239 & 5.21 & 14.84 & 34.90 & 26.98 & 6.88 & 30.67 & 5.65 & 1.13 & 1.99 & 0.85 & 6.18 & 1.51 & 4.97 & 4.54 & 0.86 \\
\hline CTD6-B7 & 618 & 73 & 3.98 & 16.74 & 42.63 & 45.63 & 7.89 & 33.15 & 6.68 & 1.46 & 3.40 & 0.93 & 6.44 & 1.61 & 5.28 & 5.05 & 0.88 \\
\hline CTD6-B8 & 618 & 80 & 4.22 & 15.48 & 41.59 & 36.90 & 7.19 & 31.29 & 6.82 & 1.30 & 2.59 & 0.89 & 6.28 & 1.59 & 5.21 & 4.87 & 0.82 \\
\hline CTD6-B9 & 553 & 58 & 2.36 & 13.24 & 31.91 & 23.53 & 5.54 & 25.27 & 5.00 & 1.12 & 2.27 & 0.74 & 5.62 & 1.43 & 4.82 & 4.64 & 0.80 \\
\hline CTD6-B10 & 498 & 53 & 2.22 & 11.51 & 33.38 & 26.41 & 6.09 & 26.70 & 6.16 & 1.14 & 1.82 & 0.80 & 5.77 & 1.54 & 4.79 & 4.58 & 0.77 \\
\hline CTD6-B11 & 458 & 16 & 1.89 & & 29.13 & 17.62 & 4.84 & 22.00 & 4.95 & 0.99 & 1.64 & 0.74 & 5.56 & 1.44 & 4.67 & 4.34 & 0.72 \\
\hline CTD6-B12 & 340 & 22 & & & & & & & & & & & & & & & \\
\hline CTD6-B13 & 239 & 33 & 2.41 & 6.52 & & & & & & & & & & & & & \\
\hline CTD6-B14 & 141 & 63 & & & & & & & & & & & & & & & \\
\hline CTD6-B15 & 84 & 95 & 2.34 & 10.29 & & & & & & & & & & & & & \\
\hline CTD6-B16 & 38 & 410 & & & & & & & & & & & & & & & \\
\hline \multicolumn{18}{|c|}{ ER-CTDR-08 - Pockmark Field } \\
\hline CTD8-B2 & 537 & 2088 & 5.58 & 39.65 & 61.43 & 90.55 & 12.94 & 52.20 & 9.61 & 2.12 & 5.64 & 125 & 8.12 & 1.84 & 5.90 & 5.30 & 0.84 \\
\hline CTD8-B1 & 535 & 1984 & 5.85 & 36.54 & 180.6 & 114.6 & 17.93 & 62.20 & 10.97 & 2.09 & 6.63 & 1.32 & 8.31 & 1.99 & 6.10 & 5.46 & 0.92 \\
\hline CTD8-B3 & 533 & 1838 & 6.76 & 38.91 & 67.66 & 110.6 & 14.65 & 58.53 & 10.93 & 2.30 & 5.87 & 1.37 & 8.55 & 1.90 & 5.78 & 5.54 & 0.88 \\
\hline CTD8-B4 & 525 & 1195 & 5.10 & 32.68 & 56.55 & 86.24 & 11.88 & 49.83 & 9.38 & 2.00 & 5.04 & 1.15 & 7.91 & 1.77 & 5.51 & 5.23 & 0.83 \\
\hline CTD8-B5 & 518 & 648 & 3.58 & 20.84 & 47.69 & 58.29 & 9.36 & 39.09 & 7.78 & 1.64 & 3.49 & 1.02 & 7.03 & 1.70 & 5.47 & 5.14 & 0.85 \\
\hline CTD8-B6 & 490 & 856 & 4.31 & 18.33 & 41.49 & 46.18 & 7.97 & 34.68 & 6.78 & 1.50 & 225 & 0.95 & 6.46 & 1.59 & 5.05 & 4.61 & 0.74 \\
\hline CTD8-B7 & 411 & 119 & 2.60 & 18.52 & 34.40 & 21.51 & 5.97 & 26.14 & 5.35 & 1.10 & 9.52 & 0.78 & 5.64 & 1.44 & 4.42 & 4.33 & 0.73 \\
\hline CTD8-B8 & 411 & 126 & 2.41 & 13.31 & & & & & & & & & & & & & \\
\hline CTD8-B9 & 335 & 276 & 1.95 & 11.38 & 32.21 & 19.78 & 5.41 & 25.19 & 4.73 & 1.15 & 1.58 & 0.75 & 5.63 & 1.35 & 4.40 & 3.97 & 0.65 \\
\hline CTD8-B10 & 283 & 63 & 2.21 & 11.31 & 31.65 & 20.90 & 5.44 & 24.66 & 5.37 & 1.16 & 6.79 & 0.76 & 5.49 & 1.35 & 4.28 & 3.88 & 0.65 \\
\hline CTD8-B11 & 223 & 40 & 1.23 & 8.62 & 26.66 & 15.40 & 4.41 & 20.26 & 5.11 & 0.89 & 2.30 & 0.64 & 4.90 & 1.22 & 4.07 & 3.45 & 0.57 \\
\hline CTD8-B12 & 223 & 64 & 1.23 & 6.33 & & & & & & & & & & & & & \\
\hline CTD8-B13 & 97 & 49 & 1.10 & 6.68 & & & & & & & & & & & & & \\
\hline CTD8-B14 & 57 & 160 & 3.17 & 13.34 & & & & & & & & & & & & & \\
\hline CTD8-B15 & 57 & 458 & & & & & & & & & & & & & & & \\
\hline
\end{tabular}


Table 2

Dissolved REE concentrations and Nd isotope data for Niger Delta seawater samples.

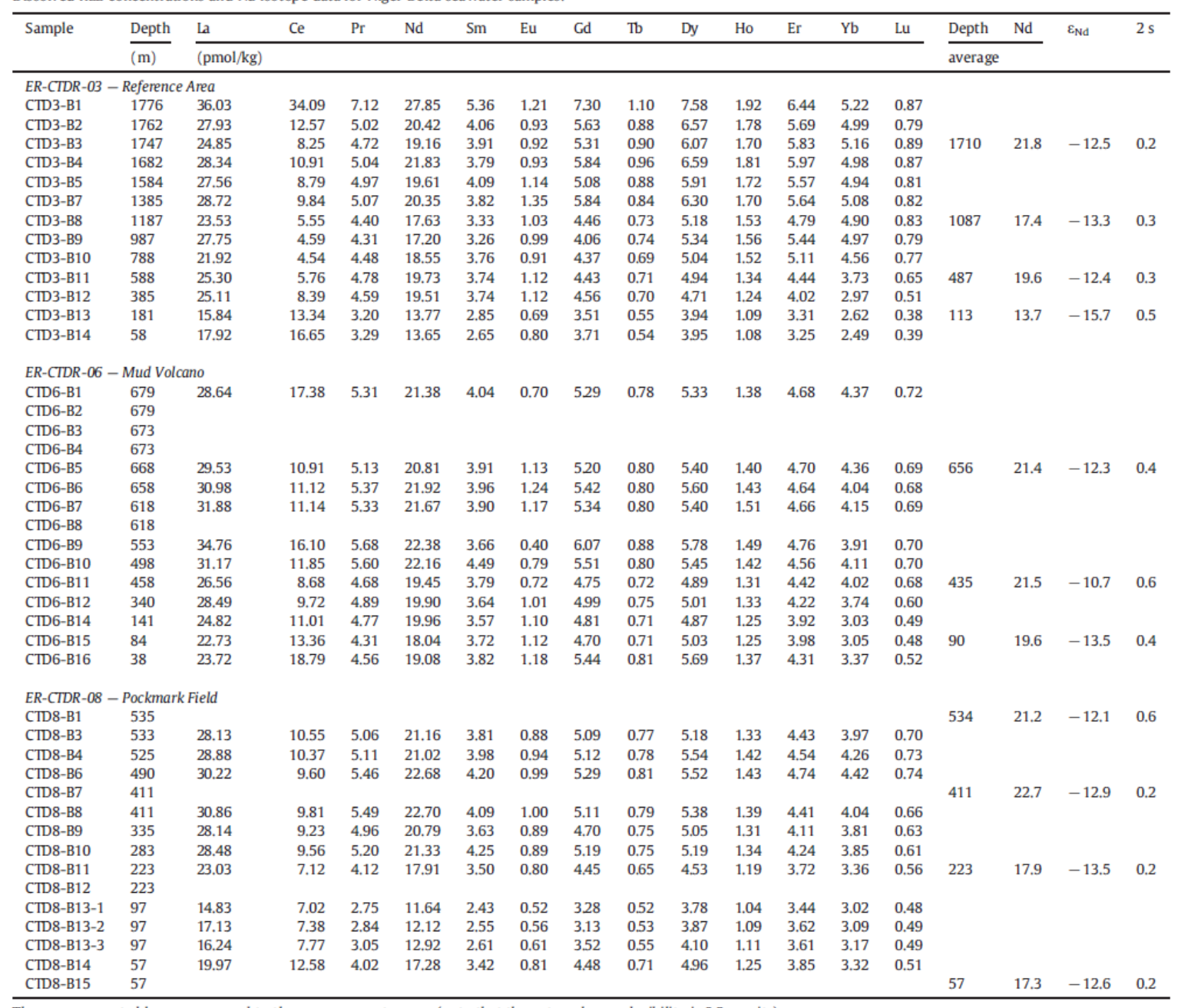

The errors reported here correspond to the measurement errors (note that the external reproducibility is $0.2 \varepsilon$ units).

Table 3

Dissolved REE concentrations for pore water samples at active Niger Delta seeps.

\begin{tabular}{|c|c|c|c|c|c|c|c|c|c|c|c|c|c|c|}
\hline \multirow[t]{2}{*}{ Sample } & Core depth & La & $\mathrm{Ce}$ & $\mathrm{Pr}$ & $\mathrm{Nd}$ & $\mathrm{Sm}$ & $\mathrm{Eu}$ & $\mathrm{Gd}$ & $\mathrm{Tb}$ & Dy & Ho & $\mathrm{Er}$ & $\mathrm{Yb}$ & Lu \\
\hline & $(\mathrm{cm})$ & \multicolumn{13}{|c|}{$(\mathrm{pmol} / \mathrm{kg})$} \\
\hline \multicolumn{15}{|l|}{ Mud Volcano } \\
\hline ER CS 40 & $0-2$ & 185 & 563 & 65.9 & 266 & 49.9 & 9.3 & 39.1 & 62 & 38.5 & 7.9 & 23.8 & 19.0 & 2.6 \\
\hline \multicolumn{15}{|l|}{ Pockmarks } \\
\hline N2-KI-41 & $0-2.5$ & 485 & 1439 & 133 & 518 & 95.1 & 22.0 & 74.5 & 10.0 & 52.6 & 10.1 & 26.7 & 23.9 & 3.7 \\
\hline N2-KI-41 & $15-20$ & 382 & 1117 & 103 & 388 & 68.5 & 15.5 & 67.6 & 9.0 & 47.3 & 9.9 & 28.2 & 25.4 & 4.3 \\
\hline
\end{tabular}


Table 4

REE concentrations of easily leachable sediment fractions and cold seep carbonates.

\begin{tabular}{|c|c|c|c|c|c|c|c|c|c|c|c|c|c|c|}
\hline \multirow[t]{2}{*}{ Sample } & Core depth & La & $\mathrm{Ce}$ & $\operatorname{Pr}$ & $\mathrm{Nd}$ & Sm & Eu & Gd & $\mathrm{Tb}$ & Dy & Ho & Er & $\mathrm{Yb}$ & Lu \\
\hline & $(\mathrm{cm})$ & \multicolumn{13}{|l|}{$(\mathrm{ppm})$} \\
\hline \multicolumn{15}{|c|}{ Dilute $\mathrm{HNO}_{3}$ sediment $(<45 \mu \mathrm{m}$ fraction) leachates } \\
\hline N1-KSF-01 & $0-2$ & 71 & 238 & 19.4 & 74 & 14.4 & 3.0 & 12.8 & 1.9 & 9.8 & 1.8 & 5.1 & 3.9 & 0.52 \\
\hline N1-KSF-42 & $0-2$ & 79 & 261 & 22.6 & 88 & 173 & 4.0 & 15.6 & 2.1 & 11.2 & 2.1 & 5.8 & 4.5 & 0.63 \\
\hline ER-CS-38 & $0-2$ & 113 & 371 & 32.8 & 132 & 25.9 & 5.7 & 21.6 & 3.0 & 14.7 & 2.6 & 7.1 & 5.2 & 0.70 \\
\hline ER-CS-40 & $0-2$ & 22 & 80 & 9.1 & 41 & 103 & 2.4 & 11.0 & 1.7 & 9.1 & 1.8 & 4.6 & 3.6 & 0.49 \\
\hline \multicolumn{15}{|c|}{ Authigenic carbonates } \\
\hline ER-CS-38 & 500 & 8.2 & 21.0 & 2.17 & 8.5 & 1.59 & 0.35 & 1.35 & 0.21 & 1.08 & 0.21 & 0.56 & 0.45 & 0.06 \\
\hline ER-CS-40 & 5 & 3.3 & 7.7 & 0.85 & 4.1 & 0.94 & 0.21 & 0.72 & 0.09 & 0.45 & 0.08 & 0.21 & 0.15 & 0.02 \\
\hline
\end{tabular}

Table 5

Nd isotope data for core-top sediment fractions and cold seep carbonate samples.

\begin{tabular}{|c|c|c|c|}
\hline \multirow[t]{2}{*}{ Sample } & Core depth & $\varepsilon_{\mathrm{Nd}}$ & $2 \mathrm{~s}$ \\
\hline & \multicolumn{3}{|l|}{$(\mathrm{cm})$} \\
\hline \multicolumn{4}{|l|}{ Reference Area } \\
\hline \multicolumn{4}{|l|}{ N1-KSF-01 } \\
\hline Uncleaned forams & $0-2$ & -12.54 & 0.08 \\
\hline Dilute $\mathrm{HNO}_{3}$ leachate & $0-2$ & -11.9 & 0.2 \\
\hline Detrital sediment & $0-2$ & -11.79 & 0.08 \\
\hline \multicolumn{4}{|l|}{$\mathrm{N} 1-\mathrm{KSF}-42$} \\
\hline Uncleaned forams & $0-2$ & -12.69 & 0.08 \\
\hline Dilute $\mathrm{HNO}_{3}$ leachate & $0-2$ & -112 & 0.5 \\
\hline Detrital sediment & $0-2$ & -11.70 & 0.08 \\
\hline \multicolumn{4}{|l|}{ Mud Volcano } \\
\hline \multicolumn{4}{|l|}{ ER-CS-40 } \\
\hline Dilute $\mathrm{HNO}_{3}$ leachate & $0-2$ & -112 & 0.2 \\
\hline Detrital sediment & $0-2$ & -11.23 & 0.10 \\
\hline Authigenic gypsum & $0-2$ & -11.3 & 0.2 \\
\hline Authigenic carbonate & 5 & -11.5 & 0.2 \\
\hline \multicolumn{4}{|l|}{ Pockmark Field } \\
\hline \multicolumn{4}{|l|}{ ER-CS-38 } \\
\hline Uncleaned forams & $0-2$ & -12.50 & 0.12 \\
\hline Dilute $\mathrm{HNO}_{3}$ leachate & $0-2$ & -11.1 & 0.2 \\
\hline Detrital sediment & $0-2$ & -11.79 & 0.07 \\
\hline Authigenic carbonate & 500 & -12.0 & 0.3 \\
\hline
\end{tabular}

